\title{
Endogenous Posthepatic Insulin Secretion and Metabolic Clearance Rates in the Neonatal Lamb
}

\author{
RICHARD M. COWETT, ${ }^{(17)}$ JOHN B. SUSA, DAVID WARBURTON, BARBARA STONESTREET, \\ ROBERT SCHWARTZ, AND WILLIAM OH
}

Department of Pediatrics, Women and Infants Hospital of Rhode Island and Rhode Island Hospital, and Section of Reproductive and Developmental Medicine, Brown University Program in Medicine, Providence, Rhode Island, USA

\begin{abstract}
Summary
Posthepatic insulin availability has been evaluated by steadystate insulin turnover studies with ${ }^{131} \mathrm{I}$-insulin. Spontaneously delivered term (age $3.3 \pm 0.8$ days) (mean \pm S.E.) and prematurely delivered lambs (betamathasone treated at 132 days) (age, $1.1 \pm$ 0.2 days) were compared with 4 to 5 -month-old sheep. After a 7 hr fast, animals received $0.45 \%$ saline or $5.7 \mathrm{mg} / \mathrm{kg} / \mathrm{min}$ glucose $(0.06 \mathrm{ml} / \mathrm{kg} / \mathrm{min})$ for $6-\mathrm{hr}$ followed by the tracer insulin infusion for $110 \mathrm{~min}$. Plasma glucose, insulin, and immunoprecipitable insulin were measured sequentially during the steady state. Endogenous posthepatic insulin secretion and metabolic clearance rates were derived. Neither endogenous posthepatic insulin secretion rates nor metabolic clearance rates were different among the three groups of animals when either $0.45 \%$ saline or $5.7 \mathrm{mg} / \mathrm{kg}$ / min exogenous glucose infusions were compared. Secretory response of the pancreatic $\beta$ cell to continuous glucose infusion seems similar for the term and preterm lamb when compared to adult sheep.
\end{abstract}

\section{Speculation}

Secretory capability of the pancreatic $\beta$ cell does not account for imprecise control of endogenous glucose production previously noted in a neonatal lamb model.

We have previously shown that the neonatal lamb requires a 10 -fold increase in peripheral plasma insulin concentration compared to a 3-fold increase in plasma insulin in the adult to significantly reduce endogenous glucose production (1). Although the explanation for the developmental difference in glucose control was not clear, we hypothesized that hepatic sensitivity to insulin in the neonate could explain the difference. Exogenous glucose infusion produced hyperglycemia with hyperinsulinemia, but we were unable to differentiate the effect of the latter from that of the former. These effects, however, were evaluated in a subsequent series of studies in which varying concentrations of glucose and insulin were infused to produce euglycemia and hyperinsulinemia (14). We suggested that irrespective of the plasma glucose concentration and the potential counterregulatory responses that might occur during prolonged glucose infusion, endogenous glucose production in the neonatal lamb is primarily controlled by insulin.

Incremental changes in glucose concentration influence the pancreatic beta $(\beta)$ cell secretory response (4). In neither previous study were we able to evaluate pancreatic $\beta$ cell secretory activity. We inferred from evaluation of plasma glucose and insulin concentrations during the analysis of endogenous glucose production that the pancreatic $\beta$ cell response to plasma glucose concentration was comparable for both term neonates and older adult animals.
To confirm posthepatic insulin availability in the neonatal period, steady-state insulin secretion studies were performed using ${ }^{131} \mathrm{I}$-insulin as the tracer. Plasma glucose, insulin, and insulinspecific activity were determined. Endogenous posthepatic insulin secretion and metabolic clearance rates were derived in spontaneously delivered term, prematurely delivered betamethasonetreated preterm lambs, and 4- to 5-month-old adult sheep.

\section{MATERIALS AND METHODS}

Fourteen mixed breed newborn lambs and six 4- to 5-monthold mixed breed adult sheep were the subjects of this study. The eight term animals were allowed to deliver spontaneously, and the six premature lambs delivered 40 to $50 \mathrm{hr}$ after administration of $18 \mathrm{mg}$ betamethasone intramuscularly to the fetal lamb of $132 \pm$ 1 days of gestation through a hysterotomy incision following the method of Liggins (10). The mean weight of the term animals was $4.0 \pm 0.4 \mathrm{~kg}$ (mean \pm S.E.), and they were studied at $3.3 \pm 0.8$ days. The prematurely delivered lambs weighed $3.3 \pm 0.4 \mathrm{~kg}$ at the time of study and were studied at $1.1 \pm 0.2$ days after birth. Both groups of newborn lambs were clinically well at the time of study.

The protocol of fasting, catheterization, stabilization, and initial baseline blood sampling has previously been described $(1,14)$. During the 6-hr infusion period, the animals received either $0.45 \%$ saline or $5.7 \mathrm{mg} / \mathrm{kg} / \mathrm{min}$ of exogenously administered glucose. Blood sampling for glucose and insulin was done as previously described $(1,14)$. Insulin kinetics were measured by giving $5 \mu \mathrm{Ci}$ / $\mathrm{kg} / \mathrm{min}$ of ${ }^{131} \mathrm{I}$-insulin by the prime constant infusion technique. The insulin had been iodinated by the method of Freychet et al. (3). The mean ${ }^{131}$ I-insulin-specific activity was measured using immunoprecipitable insulin activity (usually within a $\pm 10 \%$ range) on a Packard Modumatic II Auto-Gamma Scintillation Counter model 5320 (Packard Instrument Corp., Downers Grove, IL). Endogenous posthepatic insulin secretion was calculated during the steady state as follows:

$$
\mathbf{I}_{\mathrm{A}}=\frac{\mathbf{R}_{\mathrm{I}^{*}}}{\mathrm{Wt} \times\left(\mathrm{I}^{*} / \mathrm{I}\right)}
$$

The rate of appearance $\left(\mathrm{I}_{\mathrm{A}}\right)$ was assumed to be equal to the rate of production under steady-state conditions. The equation we utilized assumes that rate of appearance $\left(I_{A}\right)$ is equal to the rate of infusion $\left(R_{I^{*}}\right)$ in $\mathrm{cpm}$ divided by the weight of the animal in $\mathrm{kg}$ times the specific activity of plasma insulin $\left(I^{*} / \mathrm{I}\right)$ in counts of immunoprecipitable insulin $/ \mathrm{min} / \mu \mathrm{U}$ insulin. This is derived from the work of Steele et al. (13). The exogenous insulin tracer infused was $1 / 1000$ the plasma insulin concentration; hence, no correction for concentration of infused insulin was made.

Plasma was stored at $-70^{\circ} \mathrm{C}$ and evaluated for insulin determination by the method of Hales and Randle (7) after decay of 
the ${ }^{131}$ I. Plasma glucose was determined as previously described (1). Metabolic clearance rate was calculated by dividing the insulin secretion rate by the plasma insulin concentration (15). Statistical analysis was by unpaired $t$ tests.

\section{RESULTS}

Figure 1 shows that there were no differences in baseline plasma glucose values in all groups before the onset of the infusion. After infusions of $0.45 \%$ saline (no exogenous glucose), the term lambs evidenced an average plasma glucose concentration of $97 \mathrm{mg} / \mathrm{dl}$ (range, 94 to $100 \mathrm{mg} / \mathrm{dl}$ ) during the turnover period whereas the betamethasone-treated premature lambs evidenced an average plasma glucose concentration of $107 \mathrm{mg} / \mathrm{dl}$ (range, 73 to $133 \mathrm{mg}$ / dl) during the same period. The adult sheep, receiving no exogenous glucose, had plasma glucose concentrations averaging 86 $\mathrm{mg} / \mathrm{dl}$ (range, 67 to $104 \mathrm{mg} / \mathrm{dl}$ ) in the turnover period. There were no differences among the average concentrations of plasma glucose during the turnover period among groups.

When the three groups of animals received $5.7 \mathrm{mg} / \mathrm{kg} / \mathrm{min}$ of exogenous glucose infusion for $6 \mathrm{hr}$, the term lambs evidenced an average plasma glucose concentration of $144 \mathrm{mg} / \mathrm{dl}$ (range, 107 to $157 \mathrm{mg} / \mathrm{dl}$ ) in the turnover period. This was slightly lower than the average plasma glucose concentration noted in the premature animals of $202 \mathrm{mg} / \mathrm{dl}$ (range, 168 to $268 \mathrm{mg} / \mathrm{dl}$ ), but comparable to the plasma glucose concentrations noted in the adult sheep averaging $158 \mathrm{mg} / \mathrm{dl}$ (range, 117 to $198 \mathrm{mg} / \mathrm{dl}$ ) during the same period.

Figure 2 shows the peripheral plasma insulin concentrations of all groups receiving either $0.45 \%$ saline or $5.7 \mathrm{mg} / \mathrm{kg} / \mathrm{min}$ of exogenous glucose infusion. There were no differences in baseline plasma insulin concentrations among all groups. In groups receiving $0.45 \%$ saline (no exogenous glucose), both term lambs evidenced a plasma insulin concentration of $13 \mu \mathrm{U} / \mathrm{ml}$, the premature lambs evidenced an average plasma insulin concentration of 17 $\mu \mathrm{U} / \mathrm{ml}$ (range, 11 to $25 \mu \mathrm{U} / \mathrm{ml}$ ) whereas the adult sheep's plasma insulin concentrations averaged $22 \mu \mathrm{U} / \mathrm{ml}$ (range, 15 to $36 \mu \mathrm{U} /$ $\mathrm{ml})$. There were no differences among these mean average plasma insulin concentrations during the turnover period.

Under stimulation of exogenous glucose infusions, there was wider intra- and intergroup variability of plasma insulin concentration during the turnover period in comparison to when $0.45 \%$ saline was infused. Plasma insulin concentration rose to $43 \mu \mathrm{U} / \mathrm{ml}$

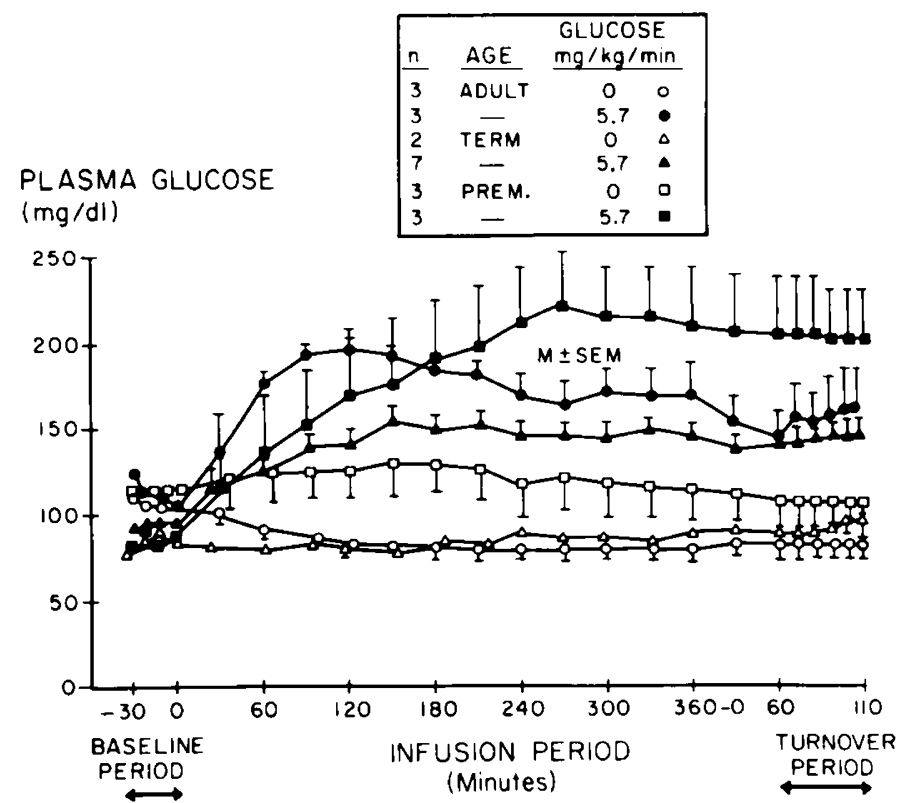

Fig. 1. Plasma glucose values in the three groups of animals after exogenous infusion of $0.45 \%$ saline or glucose.

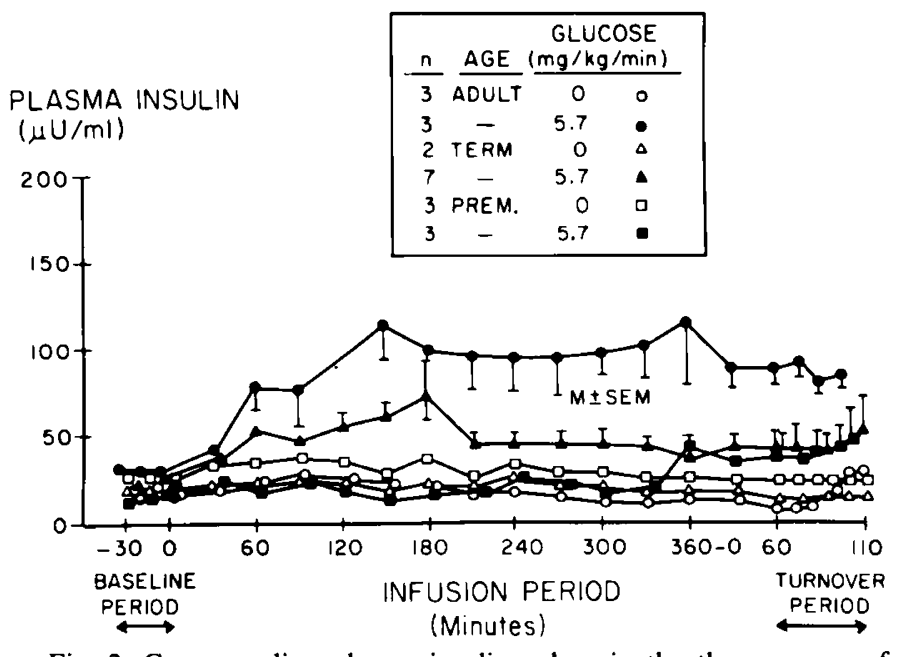

Fig. 2. Corresponding plasma insulin values in the three groups of animals after exogenous infusion of $0.45 \%$ saline or glucose.

(range, 31 to $61 \mu \mathrm{U} / \mathrm{ml}$ ) in the term lambs, $39 \mu \mathrm{U} / \mathrm{ml}$ (range, 17 to $79 \mu \mathrm{U} / \mathrm{ml}$ ) in the prematurely delivered lambs, and $86 \mu \mathrm{U} / \mathrm{ml}$ (range, 78 to $96 \mu \mathrm{U} / \mathrm{ml}$ ) in the adult sheep. The average plasma insulin concentration of the adult sheep was higher than that of the two newborn groups.

Table 1 summarizes the results of the plasma glucose, plasma insulin, posthepatic insulin secretion rate, and metabolic clearance rate for both newborn groups and the adult sheep during the turnover period under either $0.45 \%$ saline or $5.7 \mathrm{mg} / \mathrm{kg} / \mathrm{min}$ exogenous glucose infusion.

Posthepatic insulin secretion rates were not different among any of the three groups, term, premature, or adult groups, under influence of $0.45 \%$ saline infusion. Correspondingly, similar posthepatic insulin secretion rates were noted when the three groups were infused with $5.7 \mathrm{mg} / \mathrm{kg} / \mathrm{min}$ of exogenous glucose.

Metabolic clearance rates were not different among groups.

\section{DISCUSSION}

The primary objective of this study was to compare the posthepatic insulin secretion rates of the term and premature lamb with the rate noted in the adult sheep.

We have utilized the prime plus constant infusion technique as we have done previously because interpretation of tracer kinetics is simplified during metabolic steady states in contrast to when disequilibrium states are analyzed. We have used monoiodinated ${ }^{131} \mathrm{I}$-insulin as the tracer to quantify peripheral insulin secretion rates. Use of this tracer is simplified if one assumes that the specific activity includes only immunoprecipitable insulin activity because in vivo ${ }^{131} \mathrm{I}$ can be present, unattached to insulin, and fragments of ${ }^{131}$ I-insulin may be present which are not biologically significant for these analyses. To maintain the requirements of the steady-state kinetics, we have rigidly assumed that specific activity quantitation had to be within a range of $\pm 10 \%$ over a 50 -min turnover period. This is a wider range than the glucose-specific activity which usually varied less than $\pm 5 \%$ during the same period in our previous studies $(1,14)$. The increased variability of insulin-specific activity can be explained by the work of Goodner et al. (5) and Koerker et al. (9) who suggested that regular oscillation occurred over a period of $9 \mathrm{~min}$ for both insulin and glucagon and were greater by ten and five times, respectively, than for glucose. Insulin cycled in phase with glucose and these oscillations of insulin arose from changing secretion rather than degradation. One would expect a wider variability of specific activity under these circumstances in comparison to when glucose kinetics are evaluated.

We recognize that our catheters, placed peripherally (internal carotid artery for sampling), do not allow for direct measurement of insulin secretion kinetics from the pancreatic $\beta$ cell. Placement 
Table 1. Plasma glucose and plasma insulin concentrations and posthepatic insulin secretory rates as well as metabolic clearance rates during the turnover period

\begin{tabular}{|c|c|c|c|c|c|c|}
\hline Subjects & $N$ & 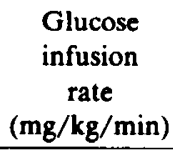 & $\begin{array}{c}\text { Plasma glucose } \\
(\mathrm{mg} / \mathrm{dl})\end{array}$ & $\begin{array}{c}\text { Plasma insulin } \\
(\mu \mathrm{U} / \mathrm{ml})\end{array}$ & $\begin{array}{c}\text { Posthepatic } \\
\text { insulin secretion } \\
\text { rate } \\
(\mu \mathrm{U} / \mathrm{kg} / \mathrm{min}) \\
\end{array}$ & $\begin{array}{c}\text { Metabolic } \\
\text { clearance } \\
\text { rate } \\
(\mathrm{ml} / \mathrm{kg} / \mathrm{min}) \\
\end{array}$ \\
\hline Term lambs & 2 & 0 & $\begin{array}{c}97^{1} \\
(94-100)\end{array}$ & $\begin{array}{c}13 \\
(13-13)\end{array}$ & $\begin{array}{c}77 \\
(69-84)\end{array}$ & $\begin{array}{c}5.9 \\
(5.4-6.5)\end{array}$ \\
\hline $\begin{array}{l}\text { Premature } \\
\text { lambs }\end{array}$ & 3 & 0 & $\begin{array}{c}107 \\
(73-133)\end{array}$ & $\begin{array}{c}17 \\
(11-25)\end{array}$ & $\begin{array}{c}69 \\
(61-84)\end{array}$ & $\begin{array}{c}4.5 \\
(2.4-5.6)\end{array}$ \\
\hline Adult sheep & 3 & 0 & $\begin{array}{c}86 \\
(67-104)\end{array}$ & $\begin{array}{c}22 \\
(15-36)\end{array}$ & $\begin{array}{c}58 \\
(44-67)\end{array}$ & $\begin{array}{c}3.0 \\
(1.9-4.2)\end{array}$ \\
\hline Term lambs & 6 & 5.7 & $\begin{array}{c}144 \\
(107-157)\end{array}$ & $\begin{array}{c}43 \\
(31-61)\end{array}$ & $\begin{array}{c}171 \\
(101-229)\end{array}$ & $\begin{array}{c}4.0 \\
(3.2-5.6)\end{array}$ \\
\hline $\begin{array}{l}\text { Premature } \\
\text { lambs }\end{array}$ & 3 & 5.7 & $\begin{array}{c}202 \\
(168-268)\end{array}$ & $\begin{array}{c}39 \\
(17-79)\end{array}$ & $\begin{array}{c}224 \\
(107-352)\end{array}$ & $\begin{array}{c}7.0 \\
(4.4-10.4)\end{array}$ \\
\hline Adult sheep & 3 & 5.7 & $\begin{array}{c}158 \\
(117-198)\end{array}$ & $\begin{array}{c}86 \\
(78-96) \\
\end{array}$ & $\begin{array}{c}224 \\
(179-263)\end{array}$ & $\begin{array}{c}2.7 \\
(1.9-3.4)\end{array}$ \\
\hline
\end{tabular}

${ }^{1}$ Average.

of catheters in the portal vein would be necessary in conjunction with measurement of portal venous flow to determine the absolute secretory rates of insulin from the pancreatic $\beta$ cell. However, the technique of portal vein catheterization is difficult and may compromise the steady state of the study animals.

We have utilized the term endogenous posthepatic insulin secretory rate to reflect our inability to measure absolute insulin secretion from the pancreas. The net plasma insulin concentration used in the calculation reflects total pancreatic insulin secretion minus the combined degradation of insulin by liver, muscle and kidney as well as renal excretion of insulin. The use of the term posthepatic reflects the major importance of the liver in this process.

Field (2) has suggested that at least under basal state conditions approximately one-half of the insulin presented to the liver is removed during a single transhepatic passage; thus, we have assumed that we could compare the three different groups of animals accordingly. Under basal conditions of $0.45 \%$ saline infusion, similar peripheral plasma concentrations of glucose and insulin were noted under the postabsorptive conditions of the study. Correspondingly, we found similar posthepatic insulin secretion rates for the three groups, term, premature lamb, and adult sheep. We infer that both the term and prematurely delivered lamb have comparable ability to that of the older sheep for secreting insulin.

Field (2) has emphasized that disagreement exists concerning the effect of an increase in glucose concentration and a concomitant increased insulin secretion on subsequent hepatic removal of insulin. Although some have suggested that a constant percentage of insulin presented to the liver was removed, other work has been interpreted to indicate that glucose administration decreased the fraction of insulin removed by the liver after a single transhepatic passage $(8,11)$. Field's work (2) substantiated the latter conclusion.

Inasmuch as there were no large differences in plasma glucose concentration during the turnover period among the three groups after glucose infusion, we have assumed that a similar percentage of insulin secreted from the pancreas was removed by the first hepatic passage. Thus, irrespective of the absolute percentage of removal of insulin by the liver, there was a similar secretory capability of the pancreatic $\beta$ cell. The similarity between term and adult groups parallels the work of Phillips et al. (12).

We utilized the technique of Liggins (10) to deliver prematurely born animals who would survive without the stress of respiratory difficulty. There is limited experience with the use of betamethasone to induce premature delivery of the lamb fetus. We have not evaluated the effect of corticosteroids specifically on either glucose or insulin kinetics in the neonate. Because glucocorticoids are known to enhance gluconeogenesis, future studies with this model should be directed toward evaluation of the prior influence of the betamethasone injection.

Our studies with these animals were completed within $48 \mathrm{hr}$ after birth to increase the possibility of optimal survival of these 131- to 134-day-old animals. There was a decrease in the initial plasma insulin concentration after exogenous glucose administration in comparison to that noted in the term lambs and adult sheep to a similar exogenous infusion. This is unexplained but parallels the work of Grasso et al. (6) who suggested that in the premature newborn exogenous glucose infusions producing plasma glucose concentrations of $>250 \mathrm{mg} / \mathrm{dl}$ resulted in only slight elevations in the plasma insulin concentration within the first $24 \mathrm{hr}$ of life. It is apparent that the initial delayed response of plasma insulin concentration was ultimately increased by the time of the turnover period so that plasma insulin concentration was not different from that found in term lamb by that time.

The metabolic clearance rates were not different when the different groups were infused with either $0.45 \%$ saline or glucose. This similarity in clearance rates confirms the similarity noted in the peripheral insulin secretion rates between the groups.

Previously, we suggested that precise control of endogenous glucose production is characteristic of the mature (adult) animal, whereas the neonate evidences a decreased ability to suppress endogenous glucose production under conditions of exogenous glucose infusion. The present studies have shown that there is a similarity in posthepatic insulin secretion rate and metabolic clearance rate in term lambs and prematurely delivered lambs in comparison to 4-5 month old sheep. We suggest that the imprecise control previously noted in the neonate in response to exogenous glucose is not related to secretory capability of the pancreatic $\beta$ cell.

REFERENCES AND NOTES

I. Cowett, R. M., Susa, J. B., Oh, W., and Schwartz, R.: Endogenous glucose production during constant glucose infusion in the newborn lamb. Pediatr. Res., 12: 853 (1978).

2. Field, J. B.: Extraction of insulin by liver. Ann. Rev. Med., 24: 309 (1973).

3. Freychet, P., Roth, J., and Neville, D. M.: Monoiodo insulin: demonstration of its biological activity and binding to fat cells and liver membranes. Biochem. Biophys. Res. Commun., 43: 400 (1976).

4. Gerich, J. E., Charles, M. A., and Grodsky, G. M.: Regulation of pancreatic insulin and glucagon secretion. Ann. Rev. Physiol., 38: 353 (1976).

5. Goodner, C. J., Walike, B. C., Koerker, D. J.. Esinck, J. W., Brown, A. C., Chideckel, E. W., Palmer, J., and Kulnary, L.: Insulin, glucagon and glucose exhibit synchronous sustained oscillations in fasting monkeys. Science (Wash. D. C.), 195: 177 (1977).

6. Grasso, S., Saporito, N., Merrina, A., and Reitano, G.: Serum insulin response to glucose and amino acids in the premature infant. Lancet, 2: 755 (1968).

7. Hales, C. N., and Randle, P. H.: Immunoassay of insulin with insulin antibody precipitates. Biochem. J., 88: 137 (1963).

8. Kaplan, N., and Madison, L. L.: The effects of endogenous insulin secretion on 
the magnitude of hepatic binding of labelled insulin during a single transhepatic circulation in human subjects. Clin. Res.. 7: 243 (1959).

9. Koerker, D. J., Goodner, C. J., Hansen, B. W., Brown, A. C., and Rubenstein. A H.: Synchronous, sustained oscillation of C-peptide and insulin in the plasma of fasting monkeys. Endocrinology, 102: 1649 (1978).

10. Liggins, G. C.: Premature delivery of foetal lambs infused with glucocorticoids J. Endocrinol., 45: 515 (1969).

11. Madison, L. L., and Unger, R. H.: The physiological significance of the secretion of endogenous insulin into the portal circulation. I. Comparison of the effects of glucagon-free insulin administered via the portal vein and via a peripheral vein on the magnitude of hypoglycemia and peripheral glucose utilization. J. Clin. Invest., 37: 631 (1958).

12. Phillips, A. F., Carson, B. S., Meschia, G., and Battaglia, F. C.: Insulin secretion in fetal and newborn sheep. Am. J. Physiol., 235: E467 (1978).

13. Steele, R., Wall, J. E., DeBodo, R. C., and Altszuler, N.: Measurement of size and turnover rate of body glucose pool by the isotopic dilution method. Am. J. Physiol.. 187: 15 (1956).

Copyright $(1980$ International Pediatric Research Foundation, Inc. $0031-3998 / 80 / 1412-1391 \$ 02.00 / 0$
14. Susa, J. B., Cowett, R. M., Oh, W., and Schwartz, R.: Suppression of gluconeogenesis and endogenous glucose production by exogenous insulin administration in the newborn lamb. Pediatr. Res., 13: 593 (1979).

15. Varma, S., Nickerson, H., Cowan. J. S., and Hetenyi, G., Jr.: Homeostatic response to glucose loading in newborn and young dogs. Metabolism, 22: 1367 (1973).

16. The authors wish to acknowledge the technical assistance of William Macomber and Betty Kelley and the secretarial assisțance of Donna Perry and Sandra Vadnais.

17. Requests for reprints should be addressed to: Richard M. Cowett. M.D., Department of Pediatrics, Women and Infants Hospital, 50 Maude Street, Providence, RI 02908 (USA).

18. This research was supported in part by National Institute of Child Health and Human Development Diabetes Center Grant HD-I1343 and the Rhode Island Hospital Research Fund.

19. Received for publication October 9, 1979.

20. Accepted for publication April 10, 1980. 